\title{
Third (2011) UK Purine Club annual symposium report
}

\author{
Bronwen Evans • Jack Ham • Emma Kidd • \\ Bill Wilkinson
}

Received: 10 February 2012 / Accepted: 13 February 2012 / Published online: 24 February 2012

(C) Springer Science+Business Media B.V. 2012

The third UK Purine Club annual symposium was held at the Park Thistle Hotel in Cardiff, South Wales on November $2^{\text {nd }}, 2011$. Despite having a reputation of being a wet city, the weather was kind and it was a dry day! The Park Thistle Hotel (built in 1883) is a grand Victorian building with a distinctive French-influenced façade. It reopened in 2008 following a multi-million pound refurbishment, so the facilities available were very comfortable and modern. Holding the meeting at such a venue was only possible because of the generous financial support given by Tocris Bioscience, Ascent Scientific, Bioline, New England Biolabs, Promocell, Sarissa Biomedical, and VWR.

The meeting was attended by over 70 people from all over the UK and further afield (Denmark, Italy, Netherlands, and Russia). Thirty seven abstracts had been received and these had been scored and ranked by five members of the UK Purine Club (Richard Evans, Alison Gartland, Jack Ham, William Wilkinson, Alex Verkhratsky) before being subdivided into 11 short oral communications and 26 poster presentations.

The one-day meeting was opened by Professor Ole Petersen, Director of the School of Biosciences at Cardiff University and the rest of the day was split into three sessions (chaired by Bronwen Evans, Jim Gallagher and Maria Abbracchio). The first invited talk was given by a 'local boy', Professor Chris McGuigan. He talked about his groundbreaking work in the field of delivering nucleotides into cells, and two drugs (INX189, which is active against hepatitis C

B. Evans $(\bowtie) \cdot$ J. Ham $\cdot$ E. Kidd $\cdot$ B. Wilkinson

Cardiff University,

Cardiff, UK

e-mail: EvansBA@cardiff.ac.uk and FV100, an anti-shingles drug) originally developed by his group have recently successfully completed initial phase 2 clinical trials There were then four short communications before a break for lunch and a poster session. After this the second invited speaker, Professor Maria Abbracchio, presented her fascinating work on the P2Y-like GPR17 receptor, followed by 4 more short communications. After a break and more discussions around the posters, the third invited speaker, Dr Stuart Mundell, talked on his exciting work on P2Y12 receptor structure/function. Following the final three short communications, Professor Geoff Burnstock closed the meeting by 'teasing' the audience with snippets from work soon to be published in a Special Edition of Purinergic Signalling entitled 'Cell and Molecular Biology of Purinergic Signalling'. He also presented the prizes for the best oral communication (Ms Swati Gupta, University of Sheffield) and poster presentation (Ms Melina Figueiredo, University of Bristol). A networking session with drinks and nibbles closed the daytime events.

In the evening 37 delegates enjoyed the conference dinner at the Park Plaza Hotel in Cardiff, although by this time it was raining! It was a well received evening and one well-known delegate wrote on the feedback form that 'it was the best conference dinner' he had ever attended. High praise indeed, since this individual will have attended a huge number of such events during his long and successful career. For some of the more energetic delegates, the day ended dancing away the night at a local nightclub!

We really enjoyed planning and hosting the 2011 UK Purine Club annual symposium in Cardiff. We would like now to hand over to Samuel Fountain at the University of East Anglia in Norwich, and look forward to attending the 2012 event. 